\title{
Risk Factors for Steroid Dependency in Children with Idiopathic Nephrotic Syndrome in India
}

\author{
Lesa Dawman $^{1}$ (D) $\cdot$ Amarjeet Mehta $^{1} \cdot$ Indar Kumar Sharawat $^{1} \cdot{\text { Rajeev } \text { Yadav }^{2}}^{2}$
}

Received: 18 May 2015 / Accepted: 9 June 2015 / Published online: 3 July 2015

(C) Dr. K C Chaudhuri Foundation 2015

To the Editor: Minimal change nephrotic syndrome (MCNS) is the most common cause of idiopathic nephrotic syndrome (INS) with a 2:1 predilection for boys. INS has a more favourable prognosis and is characterised by steroid responsiveness in approximately $90 \%$ of patients $[1,2]$. The incidence of relapse rate is high and approximately half of them develop steroid dependency. Many predictors of steroid dependency have been proposed i.e., duration from initial steroid therapy to response, concomitant upper respiratory tract infection during relapse, relapse during the first half year after disease onset, low serum protein level, gender, age at onset, total cholesterol and steroid regimen used.

We conducted our study to determine the predictive risk factors for development of steroid dependency in children with INS. The records of 125 children with steroid responsive INS were retrospectively studied; out of which 38 children $(23.4 \%)$ were steroid dependent. It was found that time duration of remission $(<10 \mathrm{~d})$ from start of therapy $(p 0.00$, OR= $1.1,95 \% \mathrm{CI}=1.0-1.1)$ and steroid regime other than $6 \mathrm{wk}$ daily $(2 \mathrm{mg} / \mathrm{kg})+6 \mathrm{wk}$ alternate day $(1.5 \mathrm{mg} / \mathrm{kg})(p 0.01, \mathrm{OR}=$ 5.6, $95 \% \mathrm{CI}=1.3-24.3)$ were found as significant predictors.

The relapsing nature of the disease presents a major challenge, and $60 \%$ of the patients have a high relapse rate [3], with a subsequent risk of steroid toxicity and complications and with half of those relapsing eventually becoming steroid dependent [4].

By early identification of those children who are likely to develop steroid dependency and its attendant morbidity, the attending clinician will be able to plan the long term management of these children and minimizing the steroid side effects.

Conflict of Interest None.

Source of Funding None.

\section{References}

1. Chesney RW. The idiopathic nephrotic syndrome. Curr Opin Pediatr. 1999;11:158-61.

2. Robson WL, Leung AK. Nephrotic syndrome in childhood. Adv Pediatr. 1993;40:287-323.

3. Ruth EM, Kemper MJ, Leumann EP, Laube GF, Neuhaus TJ. Children with steroid-sensitive nephrotic syndrome come of age: long-term outcome. J Pediatr. 2005;147:202-7.

4. Constantinescu AR, Shah HB, Foote EF, Weiss LS. Predicting firstyear relapses in children with nephrotic syndrome. Pediatrics. 2000;105:492-5.
Lesa Dawman

lesadawman@gmail.com

1 Department of Pediatric Medicine, SMS Medical College, Jaipur, India

2 Department of Preventive \& Social Medicine, SMS Medical College, Jaipur, India 